\title{
Politeness Strategies in Asking Request among Javanese Youth in Tulungagung
}

\author{
Sukarsono', Mohamad Jazeri², and Kojin ${ }^{3}$ \\ \{sukarsono71@gmail.com ${ }^{1}$, mohamadjazeri69@gmail.com ${ }^{2}$, kojinmashudi@gmail.com ${ }^{3}$ \} \\ 1,2,3 IAIN Tulungagung, East Java, Indonesia
}

\begin{abstract}
The willingness to respect and appreciate to other is the basic of mutual interaction. This study aims at describing the politeness behaviour of youth in Tulungagung, one of the regencies of East Java in Indonesia. This study is qualitatively approached, in particular utilzing pragmatics framework. The data in the forms of utterances containing directive acts made by Tulungagung youths. They were collected through observation technique. The obtained data were analyzed based on pragmatics framework, particularly the theori of politeness modeled by Brown-Levinson. Based on data analysis, the study reveals the findings as follow; (1) the request demonstrated by Tulungagung youths generally conveyed by imperative and interogative sentences, implying the levels of indirectness; (2) they employ some mitigating devices in the forms of particle, word, phrase, or clause to sahow their polite behaviour; (3) the politeness strategies employed are (a) bald on record; (b) request by bald on record; (c) positive politeness, covering in-group identity markes; and (d) negative politeness, including conventionally indirect, hedging, being pesimistic, deference, and apologizing. Form the perspective of Brown and Levinson's politeness theory, it is inferred that the requestive behaviour of the youth of Tulungagung still shows relatively polite manners.
\end{abstract}

Keywords: politeness, request, indirectness, directive

\section{INTRODUCTION}

A politeness behaviour accepted by a particular group of people, both in western and eastern parts of the world points to a relative social phenomenon. On the other hand, it is revealed that the polite behaviour is also of a culture specific. For instance, Javanese people term the polite behavior as, tatakrama, kasusilan, suba-sita, unggah-ungguh, etc, the essence of which is to act and to speak politely are closely related to one's sensitivity and willingness toward the conducts of high morality and ethics. It covers such comprehensive dimensions, addressesing not only the aspect of language use but also a belief and life philosophy of Javanese people [1].

Such a study interest suggests that Javanese society is known as one of the polite living ethnics living in Asia. Paradoxically, many educated javanese and parents feel concerned with the fact that there is a shocking phenomenon of javanese youth's attitude today. There is a seemingly degraded polite attitude among them, especially those who live in urban area. Most of them are detected not to be able to use the honorific expressions well, unlike their 
predecessors. They do not even speak javanese in daily interaction among their conterparts and family and thus they show a rather impolite or less polite manner in the social interraction [2].

Such pathetic condition is at least triggered by two factors. First, the fact that most javanese live in diaglossic situation, where they use javanese in daily and informal situation but they use Indonesian as they are doing some official activities, like schooling and official working. Both languages have their own function in the community's life. In fact, such a condition tends to make javavese be used in the very informal situation. Hence, the javanenese language is judged as a low position. This fact must make them percieve that speaking javanese language is considered less prestigious and beneficial than speaking Indonesian [3].

Secondly, there is an occuring diaglossic leakage in javanese society, the situation of which some of javanese native speakers, particularly those living in urban area, do not use javanese as means of daily communication anymore. As such, the javanese youth are more distant with javanese language and culture. The distancing of youth from javanese languagesubsequently implies the lack of internalization on the socio-cultural javanese values among the youths, especially those concerned with politeness. Such a phenomenon was revealed by a study carried out by Dwiharjo (1991) discovering that they have little understanding on javanese's politeness (unggah-ungguh). In the long run, this phenomenon may gear the language to being 'dead' unless there is an effort to generate awareness of using this language as means of daily communication among javanese [3]; [1].

To sum up, the requestive act which needs to be wisely conveyed by a speaker in order to redress its inherent FTA or at least to minimize its degree of imposition in part of a hearer is closely related to politeness domain. Thus by conducting a study on people's ways in expressing this request would likely reveal the degree to which they observe politeness in their communication. In particular, this present study focused on such a question as: How do the youth of Tulungagung (YT) politely express requestive acts in their daily interactions.

\section{METHOD}

This study was qualitatively approached. The data are in the forms of utterances containing directive act made by javanese youths living in Tulungagung. They were collected through passive participant observationtechnique, by which the researcher observed the speech events in which the the subjects were involved in communication, and focused his attentions on the communicative behaviour of the interlocutors, especially the verbal ways in expressing request along with the situational contexts where the utterances occured.

Subsequently, the obtained data were analyzed based on pragmatics framework by following the analysis stages modelled by Miles \& Huberman [4]. Practically through the stages, the reseachers scrutinized the utterances containing requestive acts according to their structural as well as functional aspects. In this stage, the analysis was focused on the formal and functional constituents of the utterances that might be composed of verbal parts which functions as the redressive actions or mitigators of the impositive force of the requestive segment of the utterance. Eventally, the analysis was addressed to the politeness strategies used by the participants in conveying the requestive act based on the theory of politeness modelled by Brown-Levinson [5]. At last, the results of the analysis is geared to inferring whether YT's polite manners are degraded or not. 


\section{RESULT AND DISCUSSION}

\subsection{Asking request by bald on record Strategy}

The frequent politeness strategy used by the youths of Tulungagung in doing request is bald on record (BOR), by which the speaker expresses his or her request unambigiously so that his communicative intention is very clearly comprehended by the hearer or there is merely one unambiguously attributable intentionwithin it. The next attribute of practicing this strategy is that the speaker does not use redressive action in his the utterance, no such part of the utterance (word, phrase, or clause) is meant to mitigate the impositive force of the utterance or to save the hearer's face.Finally, this strategy is normally used by a speaker who does not fear the hearer's retributiondue to such factors as emergency, minimal imposition, and the speaker's superiority.

The data show that BOR strategy used by Tulungagung youths in revealing request is practiced in some particular contextual features. It is usually used in such contextual features as $(\mathrm{S}>\mathrm{H},+\mathrm{S},-\mathrm{F})$, where: the speaker is more superior than the hearer; they are socially close or solidary; and the conversation occurs in informal situation. See the datum below.

[1]P1: Masuk Dik!'COme in, Sist'

P2: Yo suwun. 'Ok, thank'.

Datum [1] occurs in the contextual features of $(\mathrm{S}>\mathrm{H},+\mathrm{S},-\mathrm{F})$. The speaker is a senior student of IAIN Tulungagung and the hearer is her junior. The conversation took place in a boarding house nearby the campus. The speaker invited the hearer to come into her room by practicing BOR strategy since P1's utterance is obviously has one unambiguously attributable intention, namely a $\mathrm{S}$ requests $\mathrm{H}$ to come into her room. There is no other possible act relevant in that situation. The act of requesting was directly conveyed by the verb masukwithout any mitigating words at all. The degree of FTA of the uterance is very little so that since the act is somewhat beneficial to the hearer.

\subsection{Asking request by Positive Politeness Strategy}

Other data show that in doing a request, YTs use super strategy called positive politeness. Essentially, this strategy refers to a sort of redress aimed at saving or making the positive face of the hearer, namely one's perennial desireto obtain acknowledgement, appreciation, or common ground on his or her wants, including action, achievement, or value in such a way that they are desirable to others, be contented. Such a redressive action leads to an effort of satisfying the wants by ways of conveying that all or some of the speakers' wants are also common to or desired by the hearer [5].

The data show that the YTs use two sorts of sub-strategies of positive politeness, namely ingroup identity markers, by uses of in-group usages of address forms. The obtained data show that the YTs frequently use the addressing terms like Mas, Mbak,Cah, Dik, Pak, Bu, and the like to show in-group solidarity. The uses of such addressing terms in expressing a request were found in the some particular contextual constellations. First, it is used in the contextual features of $[\mathrm{Pn}<\mathrm{Pt},+\mathrm{S},-\mathrm{F}]$, which that the speaker is less superior than the hearer; they are solidary; and the conversation occurs in informal situation. See the datum below.

[2] + He Cah, masuk lo! 'Come on guys, the class is about to start'

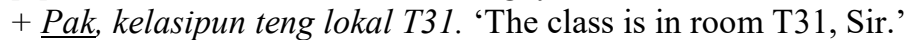

$+\underline{B u}$ anak-anak sudah menunggu di Lab 2. 'The students have been waiting in lab 2, Mom.'

Among YTs, the uses of addressing terms like Cah, Mas, Mbak, Pak, Bu are commonly practices when they engage in conversation with their friends or teachers. By means of these words, they want to suggest that both the speaker and the hearer are socially intimate since those addressing terms are in fact used among the family members. Such terms also reduce the the 
power gap of both conversation participants so that they can subsequently minimize the impositive force of the requests because of the elimination of the authority factor. As a result, the utterance sound more polite to the hearer.

Next to the use of addressing terms, YT also use code mixingin order to demonstrate ingroup solidarity. They sometimes code-mix their words betweenIndonesian and javanesein order to show the feeling of having common groundsocially as well as culturally. See the data below:

[3]P1: Pak, panjengengan hari Senin apa ke kampus? 'Do you (def) go to campus on Monday, Sir?

P2: Ya, Insyaallah. 'Yeah God's willing'

The data above is the conversation between the students $(\mathrm{P} 1)$ and a lecturer $(\mathrm{P} 2)$. The former used Indonesian language, inserted by the javanese word Panjengenan (deference: you) in order to pay respect to her teacher.The utterance of $\mathrm{P} 1$ contains indirect request, which is conveyed in interrogative form.

Another way of demonstaring common groundas used by YT is seeking the agreement between participants of the conversation. As such, the speaker attempts to find a way to adjust his wants with his hearer's. According to Brown dan Levinson (1978/87), one way to practice his strategy is by talking a safe topicin the conversation and doing repetition on partial or whole utterance of the conversation counterpart. See the datum below:

[4]P1: Nyilih kamuse ya?.'Let me borrow your dictionary, okay?'.

P2: Kamus? Lha iku jupuken ndik meja. 'Dictionary? There it is, on the table.'

In datum [4], P2 ask P1 to take the borrowed dictionary by himself on the table. Thus, the request was done by indirectly.

\subsection{Asking request by Negative Politeness Strategy}

The use of negative politeness among YT was indicated by the speaker's wants of not doing an infringement on the hearer's negative face. The speaker's redressive action is geared to partially satisfying the hearer's negative face, namely the wants of not being imposed or free from other's imposition [5].

\subsubsection{Asking request by conventionally indirect strategy}

This strategy is used when the YTs want to convey an FTA with an unambiguous intention, yet, at the same time, they want to save the hearer's negative face. The use of this strategy is indicated by verbal constructions that (1) own grammatical and lexical specific, (2) potentially own more than one function or being ambiguous, and (3) generate pragmatic duality but it is clarified and overcome by the situational context.

The way to express a request among YTs, that reflects the use of conventionally indirect strategy is by making interrogative sentence, questioning the felicity condition related to the potential ability of the hearer to do the request given by the speaker. It can be found in the following datum:

[5]P1: Sampean wis bar ta tugase? Tak nggone sik ya laptope. 'Have you (def) finished with your assignment? Let me borrow your laptop.'

P2: Wis, gaween ra pa pa.. 'That's alright, you may use it'.

In P1's utterance, there is a requestive act addressed to P2. P1 wanted to borrow P2's lap top to finish her assignment. This act was done by questioning if $\mathrm{P} 2 \mathrm{had}$ finished the assignment as an addessing remark to the ability of P2 to lend her laptop to P1. As such, P1 realized that her borrowing would not be successful if P2 was still using the laptop, thus she asked whether P2 had an ability to lend her laptop to P1. Apparently, such a question contains pragmatic 
duality, i.e. it can be interpreted by $\mathrm{P} 2$ as a mere question and a request as well. However, the context of situation leads P2 to interpreting it as a request and thus she gave an agreement response to it.

\subsubsection{Asking request by hedging strategy}

Hedging is a means of reducing the degree of FTA as the effect of the imposition contained utterance like a request. Hedges can be in the forms of a particle, a word, phrase or clause functioning to mitigate or strengthen the degree of truth of condition of an action or object presented in the proposition of the speaker's utterance. One of the commonly used hedges among YTs is a conditional clause containing the felicity condition related to the situation in which the hearer suggests that the speaker realizes that the success of his request depends on the fulfillment of conditions related to the possibilty or ablity of the hearer to do the act as requested by the speaker. Hence, the speaker usually gives a condition enabling the hearer to do the act as requested by the speaker. See the data below:

[6] P1:Yen wis bar diwaca, novele balikna ya?. 'If you have read the novel, please return it to me , okay?

P2: Ok beres. 'That's Okay'.

Data [6] contains an act of request conveyed by hedging strategy. The underlined clause is a hedge, by which the speaker assumes that the hearer cannot do the requested act, i.e. returning the novel, unless the condition is fulfilled, that is $\mathrm{P} 1$ has finished reading it. Hence, P1 is being non-coercive to $\mathrm{P} 2$ or does not push $\mathrm{P} 2$ to obey the $\mathrm{P} 1$ 's request or $\mathrm{P} 2$ can execute the request only if the condition is fulfilled.

\subsubsection{Asking request by pesimistic strategy}

This strategy refers to the assumption of the speaker that the hearer is opt out, meaning that, in the speaker's perception, the hearer has little chance to do the requested act. Thus, this strategy must make the hearer easy to refuse the act as requested by the speaker. Simply put, this strategy is underlied by the assumption of Don't assume $H$ is able/willing to do A. The use of this strategy is featured by speaker's doubt of the success of his request being executed by the hearer. Among YTs, this doubt is normally represented by a sort of tag-question, as found in the following datum.

[7] Eh, kowe duwe stipo? Tak selange dhisik entuk ye?'Hey, you've got a pen-eraser? You borrow it to, will you?'

Rik, nganggur po ra? Kancani aku yo?'Rik, are you busy or not? Come along with me, okay?'.

The requests in data [7] are conveyed by pesimistic strategy. It can be traced from the use of particle ye, which means more or less equivalent to right or po ra which means or not in English. Both particles are used to show doubton the part of the speaker. Hence, the hearer does not feel coerced at all to do or not to do the act requested by the speaker. Thus, the hearer might refuse the speaker's request at ease. By showing pesimistic attitude, the speaker can reduce the degree of imposition in his request so minimally that the hearer has no burden to deny it.

\subsubsection{Asking request by deference strategy}

Deference strategy is closely related to an attempt to satisfy oneaspect of hearer's positive face, namely the wants tobe assumed as a superior. It suggests that the speaker lowers himself or be modest to the hearer and thus the hearer is deemed to be a superior, free, and respectful person. Hence, the speaker is aware of the power owned by the hearer,that is significantly great. Among YTs, this strategy is demonstrated through the use of honorific forms, namely he choice 
of linguistic elements implying respect or deference to the hearer. The honorific forms used by YTs are in line with javanese speech levels. See the following datum.

[8] Panjenengan sak menika dhateng kampus Pak? Badhe konsultasi skripsi. 'Are you (def) in campus Sir? I would like to consult my thesis.'

Datum [8]was a short message sent by a college student, originally from Tulungagung, to his lecturer. The student asked a request to have a chance to consult his bachelor's thesis. The request was realized in interrogative and declarative forms which are encoded in javanese krama, the second highest speech level of Javanese language. The use of this krama suggests that the student wants to be modest and pays respect to his lecturer, whom he considered more superior to.

\subsubsection{Asking request by apologizing strategy}

Strategy of apologyis used by the speaker in order to suggest his reluctanceor regret. $\mathrm{He}$ feels that he has interfered or transgressed into the private area of the hearer so that the FTA is unavoided. By stating a reluctant or regretful feeling, the speaker has redressed the negative face of the hearer. The common way used by YTs is by admitting that he or she has done an impingementon the hearer. See the following datum.

[9] - Sepurane ngganggu, flash disk sing ana PPT Pak Santo tak silihe ya?'Sory for bothering, do you still keep the flash disk containing Mr. Santo's PPT, let me copy it.'

- Sory ngrepoti ya? Aku engko bareng ya mulihe? 'Sory for bothering, okay? Please give me a lift after the class.'

Both utterances above contain request which is conveyed by apologizing strategy. The underlined parts of the utterances function as the admittance of the speaker that has interfered or transgressed into the privacy of the hearer. Therefore, the speaker expressed an apology as represented by the underlined units that can redress the FTA of the request made by the speaker.

In this study, it is found that YTs is likely to use on record strategies, namely bald on record (BOR), positive politeness and negative politeness (NP). Those strategies vary in their levels of indirectness. For instance, BOR as the most direct strategy, which was used in such contextual features as $(\mathrm{S}>\mathrm{H},+\mathrm{S},-\mathrm{F})$, where: the speaker is more superior than the hearer; they are socially close or solidary; and the conversation occurs in informal situation. This implies that the most direct strategy or request is used as the $\mathrm{D}$ factor are great. This confirms Brown and Levinson, who underscore that the factor of social distance (D) is positively correlated with the degree of indirectness of realizing an FTA, which means that the less distant the interlocutors are the less indirect, or more direct, the strategy of doing an FTA is. In this case, the indirectness of the request ilocution increases as the social distance between the interlocutors is greater. It is in line with findings of some previous studies [6]; [7]; [8].

Finally, the NP politeness strategy covers (a) conventionally indirect strategy, (b) pesimistic strategy, (c) deference strategy, and (d) apologizing strategy.This strategy was mostly used in such contextual features as $(1)(\mathrm{S}=\mathrm{H},+\mathrm{S},+/-\mathrm{F})$, where: the speaker is relatively equal to the hearer; they are socially solidary; and the conversation occurs in informal situation and (2) $(\mathrm{S}<\mathrm{H},-\mathrm{S},-\mathrm{F})$, where: the speaker is less superior than the hearer; they are socially distant; and either the conversation occurs in either formal or informal situation. The latter comfims Brown and Levinson's politeness theory that the the degeree of indirectness is getting greater as the $\mathrm{R}_{\mathrm{x}}$ of imposition factor is more severe [8]; [9]; [10].

In short, the requesting behavior of YTs are in line with Brown and Levinson's model of politeness theory, particularly dealing with possible factors affecting the selection of the politeness strategies in doing FTAs. According to the model,the choice of politeness strategy in doing the FTAs is affected by such factors as social distance (D), the relative power (P) of a 
speaker over the hearer, and the rank $\left(\mathrm{R}_{\mathrm{x}}\right)$ of imposition or the act [5]. In this study, it is also found that YTs is likely to use mitigating devices in order to lessen the degree of the imposition of the request. In doing request, YTs commonly use hedging and apologizing strategy.This finding is in line with Alzeebaree, Yavuz, (2017), who found that people tend to use pre-request supportive moves elements that mitigate or reduce the level of imposition in the request. The increase of of indirectness can promote the level of politeness [11]; [12].

Finally it is also found that YTs often used conventionally indirect strategy in doing request regardless the specific context of communication. Such a finding confirms Muthusamy and Farashaiyan (2016) who concluded their study that the use of conventionally indrect strategy (preparatory questions) is more ferquently used, regardless of the power, the social distance and imposition, where the request strategies affected the use of mitigating strategies in different situations [13] [14].

\section{CONCLUSION}

Viewed from its grammatical mode, the request demonstrated by YTs generally conveyed by imperative and interrogative sentences. Such used types of grammatical sentences implies that the request is conveyed by direct and conventional indirect staretgy. YTs also add the main request expressing unit with some mitigating devices in the forms of a particle, word, phrase, or clause to show their pollite behaviours. The politeness strategies employed by YTs in conveying request are (1) bald on record); (2) request by bald on record Strategy, (3) Positive Politeness Strategy: in-group identity markers, by uses of (a) in-group usages of address forms) dan (b)in-group usages of language or dialect, (4)Negative Politeness Strategy including (a) conventionally indirect strategy, (b) hedging, (c) pesimistic strategy, (d) deference strategy, and (e) apologizing strategy.

\section{REFERENCES}

[1] H. B. Mardikantoro, "Bentuk Pergeseran Bahasa Jawa Masyarakat Samin Dalam Ranah Keluarga," Litera, vol. 11, no. 2, pp. 204-215, 2012.

[2] Mulyanto, "Bentuk Krama Desa Dalam Bahasa Jawa,” Widyaparwa, vol. 44, no. 2, pp. 136-149, 2016.

[3] Rustiati, "Penggunaan bahasa Jawa ngoko dan krama di kalangan generasi muda Jawa di wilayah Madiun," Tesis Univ. Sebel. Maret, 2008.

[4] Miles \& Huberman, Qualitative data analysis: An expanded sourcebook (3rd ed.). 2014.

[5] P. Brown and S. Levinson, Politeness: Some Universals in Language Usage. 1987.

[6] S. Blum-Kulka, "Indirectness and politeness in requests: Same or different?," $J$. Pragmat., 1987.

[7] T. Holtgraves and J. N. Yang, "Interpersonal Underpinnings of Request Strategies: General Principles and Differences Due to Culture and Gender," J. Pers. Soc. Psychol., 1992.

[8] I. Syahri, "RESEMBLANCE OF INDIRECTNESS IN POLITENESS OF EFL LEARNERS' REQUEST REALIZATIONS," Indones. J. Appl. Linguist., vol. 3, no. 1, p. $148,2013$.

[9] K. H. Tan and A. Farashaiyan, "The effectiveness of teaching formulaic politeness strategies in making request to undergraduates in an ESL classroom," Asian Soc. Sci., 2012 . 
[10] A. Tawalbeh and E. Al-Oqaily, "In-directness and politeness in American English and Saudi Arabic requests: A cross-cultural comparison," Asian Soc. Sci., 2012.

[11] Y. Alzeebaree and M. A. Yavuz, "Realization of the speech acts of request and apology by middle eastern EFL learners," Eurasia J. Math. Sci. Technol. Educ., 2017.

[12] M. Y. Al-Shawesh and S. Hussin, "Investigating the Request Strategies Among the Arab International Students and Malaysian Employees at a University in Malaysia," 2016.

[13] P. Muthusamy and A. Farashaiyan, "Situational Variations in Request and Apology Realization Strategies among International Postgraduate Students at Malaysian Universities," English Lang. Teach., 2016.

[14] K. Saddhono, "Cultural and social change of foreign students in Indonesia: The influence of Javanese Culture in Teaching Indonesian to Speakers of Other Languages (TISOL)." IOP Conf. Ser.: Ear. and Envi. Sci.. vol. 126 no. 1 IOP Publishing, 2018. 